NBER WORKING PAPER SERIES

\title{
THE IMPACT AND INEFFICIENCY OF THE CORPORATE INCOME TAX: EVIDENCE FROM STATE ORGANIZATIONAL FORM DATA
}

\author{
Austan Goolsbee \\ Working Paper 9141 \\ http://www.nber.org/papers/w9141 \\ NATIONAL BUREAU OF ECONOMIC RESEARCH \\ 1050 Massachusetts Avenue \\ Cambridge, MA 02138 \\ September 2002
}

I wish to thank William Gentry, Roger Gordon and participants and the TAPES conference for helpful comments, Justin Brookshaw, Tina Lam, and Young Kim for research assistance and the National Science Foundation, the Sloan Foundation and the American Bar Foundation for financial support. The views expressed in this paper are those of the authors and not necessarily those of the National Bureau of Economic Research.

(C) 2002 by Austan Goolsbee. All rights reserved. Short sections of text, not to exceed two paragraphs, may be quoted without explicit permission provided that full credit, including $(\mathcal{C}$ notice, is given to the source. 
The Impact and Inefficiency of the Corporate Income Tax: Evidence

from State Organizational Form Data

Austan Goolsbee

NBER Working Paper No. 9141

September 2002

JEL No. H25, L22

\title{
$\underline{\text { ABSTRACT }}$
}

By double taxing the income of corporate firms but not unincorporated firms, taxes can play an important role in a firm's choice of organizational form. The sensitivity of the organizational form decision to tax rates can also be used to approximate the efficiency cost of the corporate income tax. This paper uses new cross-sectional data on organizational form across states compiled in the Census of Retail Trade to estimate this sensitivity. The results document a significant impact of the relative taxation of corporate to personal income on the share of economic activity that is done by corporations including sales, employment, and the number of firms. The impacts are substantially larger than those found in the previous empirical literature based on time-series data.

\author{
Austan Goolsbee \\ Graduate School of Business \\ University of Chicago \\ 1101 E. 58th Street \\ Chicago, IL 60637 \\ and NBER \\ goolsbee@gsb.uchicago.edu
}




\section{Introduction}

The corporate income tax generates a distortion by double taxing corporate income. In other words, corporations typically pay income tax on income earned at the corporate level and then shareholders pay personal income tax upon the income when it is distributed to them. The fact that the taxation of corporate income generally exceeds that of personal income raises the question of how distortionary the corporate income tax is - the magnitude of the deadweight loss (DWL) of the corporate income tax.

The issue is central to standard work on the subject such as Harberger (1966), Shoven (1976) or Ballard et al. (1985). In these models, some sectors (e.g., manufacturing) are assumed to be corporate sectors and other sectors to be non-corporate. A tax on the corporate sector will lead to shifting to other sectors and this generates a deadweight loss (DWL). The models are then simulated in computable general equilibrium models and tend to suggest relatively small efficiency costs-less than 20 percent of the revenue generated.

A more recent literature has sought to consider the efficiency costs of the corporate income tax in a different setting. In particular, Gravelle and Kotlikoff $(1988 ; 1989 ; 1993)$ point out that there can be both corporate and noncorporate production in the same sector. Taxing corporate income may lead to much more shifting within sector between organizational forms than across different sectors. Using such a model they predict an extremely large DWL from the corporate income tax, frequently in excess of 100 percent of the revenue generated. The key determinant of the DWL in these models is how much firms in the same industry shift to noncorporate forms in response to the corporate income tax and this is an empirically testable idea.

In principle, it should be possible to estimate the efficiency loss from the corporate income tax by examining how much a corporate tax increase induces firms to shift out of 
corporate form. This is the subject of Gordon and Mackie-Mason (1990; 1994; 1997) and Goolsbee (1998) specifically. It is also implicit in the large literature on how corporate taxes affect organizational form decisions such as Ayers et al. (1996), Carroll and Joulfaian (1997), Gentry (1994), Fullerton and Rogers (1993), Scholes and Wolfson (1990; 1991; 1992), and Plesko (1995; 1997). The results in Gordon and Mackie-Mason and in Goolsbee indicate that across different time periods, there does not seem to be much shifting in response to tax rates, suggesting that the DWL of the corporate income tax is relatively modest overall. (i.e., low shifting implies low distortions).

An underlying empirical problem in much of this literature comes from data constraints. Variation in corporate tax rates over the past 30 years has been almost. Further, the standard approach has been to look at time-series type regressions, typically at a highly aggregated level, though sometimes with a limited panel of firm level data. The problem is that when the corporate tax rate changes, such as in 1986, many other aspects of the tax code change, as well, making it difficult to be sure that one is picking up the effect of tax rates.

This paper turns to a new data source to identify the impact of the corporate income tax using cross-sectional variation in corporate tax rates in order to avoid the typical problems of the time-series based literature. It does this by looking at variations in corporate income taxes across states and combining that with unpublished data from the Department of the Census on the organizational form by 3 and 4 digit SIC code in the retail trade sector across states in 1992.

Although the census data have some problems that traditional tax data do not have, and although there the impact of state and federal corporate income taxes may differ (since firms have an easier time moving to different jurisdictions to avoid state taxes, for example) this crosssectional approach allows for a direct estimate of the impact of tax rates on corporate incentives 
to incorporate while controlling for aggregate factors. As a further matter, there is considerable interest in the subject of state corporate income taxes themselves.

This paper will examine the impact of corporate income taxes on firms' choice of organizational form decisions and the implied efficiency cost of the corporate income tax in 5 sections. Section 2 gives an overview of the way taxes may affect the organizational form choice and presents a simple model deriving the relative tax term. Section 3 summarizes the specification estimated in the paper and the data used. Section 4 presents the regression results. Section 5 concludes.

\section{Overview of organizational form choices}

\section{A. Institutional Background}

An enterprise that conducts business does not have to declare itself to be a corporation and thus can avoid any double taxation. The firm can be organized as a sole proprietorship or as a partnership in which case any income earned will flow through to the partners' or proprietor's individual income tax. Although this type of flow through entity would appear to have a tax advantage for most types of business entities, there are important non-tax factors that lead most business assets to end up in corporate form. The two most important are limited liability and access to capital markets. The investors and managers of corporations do not risk their individual assets or income when they take part in a firm. They are only liable for the amount that they have invested in the company. Corporations also have the right to trade on organized exchanges and typically have easier access to both debt and equity. Discussion of other non-tax factors relating to organizational form choices can be found in Guenther (1992) or Scholes et al (2002). 
It is important to note some exceptions to this simple dichotomy of form choice. The first is that within the corporate sector, starting in 1958, certain firms could become $\mathrm{S}$ corporations (as opposed to the traditional C corporations). Income from S corporations are flow through entities like traditional partnerships, eliminating the double taxation without losing the limited liability. S corporations limit the number of shareholders to . More details on the comparison of S and C corporations can be found in Gordon and Mackie-Mason (1997). Recent years have seen a considerable expansion in hybrid organizational forms such as the Limited Liability Partnership, etc. which somewhat blur the lines between forms. At the time of this sample (1992), all such forms other than S corporations were rare or non-existant and, as I will indicate below, $\mathrm{S}$ corporations were not especially numerous in the retail sector.

\section{B. A Simple Theory of Organizational Form}

The stylized model of a firm's decision about whether to incorporate here follows the work of Gordon and Mackie-Mason (1994) with some extensions. Assume, for simplicity, that the income generated by a firm, $\mathrm{Y}$, is the same regardless of organization type and that there is some relative non-tax benefit $\mathrm{G}$ associated with being a corporation which is itself a function of firm characteristics, $x$. The non-tax benefit is assumed to be non-taxable (e.g., something like the value of limited liability). The after-tax income from operating as a corporation each period is then

$$
I_{C}=G(x)+Y\left(1-t_{C}^{S T}\right)\left(1-t_{C}^{F}\right)\left(1-t_{e}\right)
$$


where $t_{C}^{S T}$ is the state corporate income tax rate, $t_{C}^{F}$ is the federal corporate income tax rate and $\mathrm{t}_{\mathrm{e}}$ is the tax rate on equity income. 1 That is, a firm gets $\mathrm{G}$ plus income net of corporate and equity taxes and the state tax is deductible from the federal. ${ }^{2}$

The after tax income from a noncorporate firm is then

$$
I_{N C}=Y\left(1-t_{P}^{S T}\right)\left(1-t_{P}^{F}\right) .
$$

where $t_{P}^{S T}$ is the state personal income tax rate facing the marginal investor and $t_{P}^{F}$ is the federal personal income tax rate facing the marginal investor. In words, a noncorporate firm gets no $\mathrm{G}$ but pays only personal income taxes on the income.

Clearly, the firm will prefer the corporate form whenever

$$
G(x)>Y\left(\tilde{t}_{C}+\left(1-\tilde{t}_{C}\right) t_{e}-\tilde{t}_{P}\right)
$$

where $\tilde{t}_{i}$ is the full marginal tax rate on income type $i-$ i.e., accounting for state and federal taxation—according to

$$
\tilde{t}_{i}=t_{i}^{S T}+t_{i}^{F}-t_{i}^{S T} t_{i}^{F}
$$

In the case where the effective rate of taxation on equity is zero, all that matters is the relative taxation of corporate versus personal income. The model illustrates that the key tax determinant of the decision of whether to incorporate is the relative taxation of corporate versus personal income. While each of these tax components can, to some degree, be measured, the sign of the relationship depends on whether taxable income is greater than zero and this fact that

1 I will exclude discussion of the payroll tax whose method of payment differs for corporations versus partnerships/proprietorships but whose total burden is equal.

2 This is sufficient for almost all states. In five small states, however, at the time of the sample-Alabama, Iowa, Louisiana, Maryland, and North Dakota-the previous year's federal taxes are also deductible from the state taxes. I account for this in the empirical work. 
is not observed in the census data. I will have to use proxies for profitability to examine whether this prediction is born out in the data.

This model is most relevant for small, entrepreneurial type firms. In particular, it is not a good approximation for multi-state firms. When a firm conducts business in multiple states, its marginal tax rate becomes a weighted average of tax rates in all the states it does business in according to the apportionment formula (see Gordon \& Wilson, 1986; Goolsbee and Maydew, 2000). The evidence will, indeed, show that the empirical model fits much better in industries with a small number of establishments per firm.

\section{Data}

\section{A. Specification}

The basic regression of the paper will explain the corporate share of industry activity $\mathrm{Y}$, say employment or revenue, for state s and industry i according to

$$
\frac{Y_{i s}^{\text {Corporate }}}{Y_{\text {is }}^{\text {Total }}}=\alpha_{i}+\beta\left(T A X_{s}\right)+\Gamma^{\prime} X_{i s}+\Lambda^{\prime} Z_{s}+\varepsilon_{i s},
$$

where TAX is the measure of the relative taxation of corporate income from the model above, $\left(\tilde{t}_{C}+\left(1-\tilde{t}_{C}\right) t_{e}-\tilde{t}_{P}\right), \mathrm{X}$ is a vector if state-industry characteristics that may influence the gains to incorporation, and $\mathrm{Z}$ is a vector of state level factors that may influence the likelihood of incorporation. $^{3}$

\section{B. Data on Organizational Form Across States and Industries}

3 The right hand side share variable is censored at 0 and 1 in a few cases (1-3 percent or the state-industries). In the results below I will use the linear regression model for simplicity, especially in dealing with the fixed effects. I have checked the results but using a Tobit estimator with censoring at 0 and 1 and the results were virtually identical. 
The data on organizational form come from the Census of Retail Trade for 1992. This economic census is conducted every five years and is meant to provide comprehensive coverage of the sector. Retail trade, being primarily a non-tradeable, may not be representative of other sectors of the economy. It may, for example, be more sensitive to organizational form decisions than other industries are (for those industries, it is easier to change the location of production). That said, retail trade is an enormous sector on its own accord. In 1992, total sales in the retail trade sectors included in this sample exceeded \$1.7 Trillion and employment was almost 17.5 million. This was divided between 8 broad classes of retail trade as shown in table 1. According to the BEA, in 1992 retail trade made up almost 9 percent of national GDP and the BLS reports that it employed about 16.5 percent of the nation's workforce.

The census of retail trade asks firms about their organizational form. The choices are corporate, partnership, sole proprietorship, and other. I will use the sum of all the non-corporate categories as the non-corporate share. One drawback of the Census data compared to tax return data is that the Census does not distinguish any of the hybrid organizational forms, most importantly, it does not differentiate $\mathrm{S}$ corporations from $\mathrm{C}$ corporations. The $\mathrm{S}$ corps are flow through entities so changes to the relative tax term may lead businesses to shift from $\mathrm{C}$ to $\mathrm{S}$ corporations in response to the tax but this will not show up as a change in the Census data since the firm will remain a corporation in both cases. This will no doubt bias the estimated impact of taxes on organizational form choices toward zero in the current sample. It is not possible to determine how important a factor this is because there is no publicly available information on the share of S corporations by state. The Statistics of income for 1992 for the entire nation, however, shows that the share of corporate returns in the wholesale and retail trade sector that are $\mathrm{S}$ corporations is about 20 percent. The share of total revenues in the corporate sector from $\mathrm{S}$ 
corporations is about 5 percent. On average, then, the misclassification of corporations is relatively small, though they may be more sensitive on the margin than are other corporations.

Similarly, there is no income information in the data because it is establishment based and income is fundamentally a firm-level concept. This will prevent all but the most crude proxy for the differential responses of gain versus loss firms.

I received a special tabulation from the Census Bureau for each reported SIC code and each variable (employment, payroll, sales, firms, establishments) the totals by organizational form type. I will use the corporate share of the industry total as the dependent variable in the regressions. These special tabulations are subject to non-disclosure requirements meaning that the Census does not reveal information that could be used to learn about specific companies. So, for example, SIC code 5943, Stationery Stores is missing information on employment and sales in several smaller states. The missing observations are concentrated among the small states and the small industries, of course. In the 76 industries 3-digit industries, of the 1900 possible industry-state combinations, 15 have data on the number of corporate firms and establishments withheld for disclosure reasons. More of the employment, payroll and sales observations are withheld with about 210 of the 1900 possible observations missing for the corporate sector in these areas.

The data include information on the SIC codes listed in the Appendix table. I will mainly focus on the 3 digit SIC code level, though I will also present some results at the 2- and the 4digit level. At lower levels of aggregation, not all the industries are covered. One of the big advantages of looking at the retail trade data is that there are many industries with a great deal of non-corporate activity, unlike manufacturing and some other prominent sectors. There is also a great deal of variation in the corporate share. 


\section{B. Data on Taxes and Other Control Variables}

The components of the tax term are computed as follows: the combined federal and state tax on personal income for the marginal investor is the highest marginal rate in the state, combining federal and state taxation, as computed by the NBER TAXSIM for the year 1992 as reported in NBER (2002). For the corporate rate, I use the information in the Book of the States (1994) as well as Significant Features of Fiscal Federalism (ACIR, 1994) and compute the highest corporate marginal rate in the state, taking account of the deductibility of state taxes from the federal and the reverse in the relevant states. Michigan does not have conventional corporate income tax so I exclude it from the results.

The model above seems to outline the decision of the organizational choice of a small entrepreneur. For such a person, the tax on equity is different than for a larger company. Since small firms are unlikely to pay any dividends, however, and because there are several aspects of capital gains that are highly favorable to small entrepreneurs (greater deductibility of losses from ordinary income, for example), it it probably more accurate to assume the tax rate on equity is zero. I will do that here. Results were similar assuming equity taxation at the highest state capital gains rate, discounted for delayed realization as in Feldstein et al. (1983), instead, as demonstrated in an earlier version of this paper (Goolsbee, 2002).

Figure 1 plots $\tilde{t}_{C}$ for each state on the y-axis and $\tilde{t}_{P}$ on the x-axis. The difference between the two is the tax term so states well above the 45 degree line like Alaska, Pennsylvania and Connecticut tax corporate income relatively heavily compared with personal income and 
places closer to or actually below the 45 degree line like South Carolina, Kansas and Vermont tax corporate income relatively lightly. 4

Industry characteristics that might influence the probability of incorporation (through, say, increasing the value of limited liability or access to capital markets) might be average firm size, pay, number of establishments per firm and the like. To keep things as general as possible, I will include the log of total industry sales, employment, payroll, number of firms and number of establishments. I tried including various ratios such as population density, sales per firm and so on, instead of the logs and the results were the same. Note that because there are dummies for every SIC code, the specifications fully account for any industry level variation in non-tax reasons for incorporation.

There may also be state characteristics that might influence the probability of incorporation in all industries. It is impossible to include state dummies since the tax rate does not vary across industries but I will include information on the log of the Gross State Product in the state in the year of the sample (1992) and the previous year (1991) from the BEA, the log of the land area and the log of population in the state from the U.S. Statistical Abstract and the share of the state population born outside the state (either domestic or foreign born) and the share of the people born in the state that are still living in the state both at the time of the 1990 census, calculated from U.S. Department of the Census (2002) as well as the share of the state that is rural. The view is that state income levels or growth rates, concentration of population, tax competition pressures from neighboring states or a higher transient/new population all might influence the probability of incorporation. I also include the share of the state that has some

4. The regressions will take these tax rates as exogenous. Though I do not have information about how the state tax rates were determined, I did try including other types of taxes which might be correlated with the unobserved business climate in the state such as the sales tax rate and generally did not find that it changed the results presented. 
college education in the spirit of the theoretical work of Levin and Tadelis (2002). All of the state level data, including the tax rates, summarized in Table 2.

\section{Results}

A. Basic Results

Results from the basic specification explaining the corporate share of firms, establishments, employment, payroll, and sales in a given industry in a given state as a function of the relative tax term and the other control variables are reported in table 3 . This is for 38 different industries at the 3-digit SIC code level. There are SIC code dummies for the industries so the coefficients indicate the impact that a state having a higher relative tax on corporations has on its share of corporate activity relative to other states in that same industry. For each of the types of economic activity, the coefficient on taxes is negative (and significant for all but one) indicating that increasing the relative burden on corporations reduces the corporate share of activity.

The coefficient on firms indicates that every .01 rise in the corporate income tax reduces the corporate share of firms by .006 . Interestingly, the results indicate that the share of firms responds much more to the tax term than does the share of establishments. Similarly, the share of employment, payroll and sales responds negatively, as well, but by less than does the number of firms (this is especially true considering that the corporate share is higher for these variables than for the number of firms). The number of firms may be more responsive than other categories because state corporate tax rates are frequently progressive and a small firm can remain in the lower marginal tax rate by simply starting a new firm rather than by growing. 
The magnitudes of the tax coefficients are not precisely comparable to the effects estimated in the literature by Gordon and Mackie-Mason (1994; 1997) or Goolsbee (1998) because those papers dealt with the corporate share of capital or the share of reported income whereas these are for the number of firms and establishments and the level of sales, employment and payroll. That said, the coefficients on the tax term here are substantially larger than on the same tax term in those papers. The coefficients of the tax term on the share of industrial activity done by corporations here ranges from -.17 to -.60 . The equivalent coefficients in the previous literature (on the overall corporate share of capital assets) generally ranged from -.001 to -.15.

\section{B. Robustness}

Next, in table 4, I examine the results at different levels of aggregation. For brevity, I will look at the corporate share of firms, employment and sales and leave establishments and payroll out of the tables. The results are highly related, just as in the previous table. At the 2digit SIC code level, there is data is available for all of the industries, although there are only 8 SIC codes so the estimates are not estimated very precisely. The results, presented in columns (1)-(3) show a similar pattern with similar magnitudes but larger standard errors. For a subset of industries, there is more detailed data, i.e., down to the 4-digit SIC code level. These are concentrated only in the 2-digit SIC codes 57, 58 and 59. Looking at these 30 industries in columns (4)-(6) shows even larger effects than the 3-digit results did, especially for the 'real' factors of employment and sales.

In table 5, I deal with the robustness questions that might arise from weighting stateindustries equally despite dramatically varying sizes. In theory, since the regressions are controlling for size of population of the state and the size of the sector, this should not matter but 
there may be differences in the responsiveness for different sized industries. Columns (1)-(3) reestimate the regressions but weight them by state population size. The coefficients are of greater magnitude than before. Columns (4)-(6) present results from a median regression on the same data which again show that the magnitudes are not being driven by a small number of outliers or a few small states. The results here are even more sensitive to tax rates.

\section{Explaining Differing Tax Sensitivities}

Table 6 examines the issue of multi-establishment firms. Because of the higher probability of being multi- state firms (and thereby having tax rates that differ from the tax rates in the one state), firms with more establishments should appear less sensitive to state relative tax rates than do single establishment firms. The data do not go down to that level of detail but I can divide the observations between industries with average establishments per firm less than 2 and those with greater than or equal to 2 . As the number of observations indicate, the majority of firms are in the few-establishments group, though there are about 10-15 percent in the multiple establishment group. As predicted, the corporate share of firms, employment and sales is quite significantly related to taxation among firms with a low number of establishments. This is presented in columns (1), (3) and (5). For firms with many establishments, presented in columns (2), (4) and (6), there is no significant effect of the tax rate in an individual state and the coefficients are much smaller.

Table 7 explores two things that ought to influence the tax sensitivity of various stateindustries. The theory demonstrated that the impact of the tax term should have opposite signs for tax loss firms as for tax gain firms. In the Census data, of course, there is not even accounting profit information, much less reported taxable income. As a proxy, though, I will use 
the ratio of total operating expenses relative to sales. Total operating expenses include payroll, benefits, costs of goods sold, materials and supplies, depreciation, leases, fuel and electricity but not capital expenditures. The payroll information is in the state level census data, the other operating expenses come from the national edition of the Census of Retail Trade-Assets and Expenditues Series. Some of those data are given at only the 2-digit level so I assume all SICs in the same 2-digit category have the same operating expense ratio in these cases. The measure of total expenses ranges from 71 percent of sales for Department Store Retailers to more than 98 percent of sales for Radio, Television and Music stores and for Grocery Stores.

Columns (1)-(3) interact this measure of operating expenses with the relative tax term. If the percent of sales revenue remaining after subtracting total operating expenses is a crude measure of profitability then the tax term should be less important in industries with higher expense ratios. In other words, the interaction term should be positive if the measured tax term is less important for firms making losses (i.e., with high expense ratios). The results have the correct signs although they are clearly noisy, especially as regards employment and sales.

The last 3 columns then explore whether sensitivity to tax rates is related to the physical size or to the population of the state. At the outset, I noted that the sensitivity to state corporate income taxes might be greater than to federal income taxes because corporate firms can move locations as well as change organizational status in response to local variation. In small or sparsely populated places like Vermont, firms may react very negatively to a tax increase whereas in a place like California they may want to remain in the market and as corporations no matter what the cost. To explore this, I interact the tax term with the log of population and the $\log$ of land area in the state. For the corporate share of firms in the state-industry, both variables matter. For employment and for sales, only the physical size of the state matters. In every case, 
the smaller the state, the greater is the sensitivity to relative tax differentials. The magnitudes are quite large. Take corporate employment. For a state in the 5th percentile of the size distribution (Connecticut), raising the relative tax term by .01 reduces the share of corporate share of firms in the state-industry by .014 . For a state in the 95 th percentile, the effect is zero (the point estimate is -.001$)$.

\section{Conclusion}

Using new, cross-sectional census data across states and industries in the retail trade sector, this paper has shown that the relative taxation of corporate to personal income plays an important role in the share of firms, employment and sales that are done by corporations versus partnerships and sole proprietorships. An increase in the corporate tax rate by .10 reduces the corporate share of firms by 5-10 percent and the corporate share of sales and employment by 2-6 percent. Given the lack of data on $\mathrm{S}$ corporations in the census data, this is likely to be an underestimate of the true shifting. This impact of tax rates is an order of magnitude larger than previous estimates based on time-series variation in the tax rate and suggests a larger DWL from corporate taxation but is still relatively modest. 
Table 1: Census of Retail Summary

\begin{tabular}{|c|c|c|c|}
\hline SIC CODE & Firms & $\begin{array}{l}\text { Sales } \\
(000 s)\end{array}$ & $\begin{array}{c}\text { Employees } \\
(000 \mathrm{~s})\end{array}$ \\
\hline $\begin{array}{c}\text { 52: Building Materials \& Garden Stores } \\
\% \text { Corporate }\end{array}$ & $\begin{array}{c}56,431 \\
.694\end{array}$ & $\begin{array}{l}98,730 \\
.905\end{array}$ & $\begin{array}{l}665 \\
.887\end{array}$ \\
\hline $\begin{array}{l}\text { 53: General Merchandise Stores } \\
\text { \% Corporate }\end{array}$ & $\begin{array}{c}11,520 \\
.564\end{array}$ & $\begin{array}{c}245,100 \\
.989\end{array}$ & $\begin{array}{c}2,076 \\
.985\end{array}$ \\
\hline $\begin{array}{c}\text { 54: Food Stores } \\
\% \text { Corporate }\end{array}$ & $\begin{array}{c}129,100 \\
.478\end{array}$ & $\begin{array}{c}368,600 \\
.904\end{array}$ & $\begin{array}{c}2,964 \\
.882\end{array}$ \\
\hline $\begin{array}{l}\text { 55: Auto Dealers } \\
\% \text { Corporate }\end{array}$ & $\begin{array}{l}80,213 \\
.728\end{array}$ & $\begin{array}{c}393,300 \\
.930\end{array}$ & $\begin{array}{c}1,261 \\
.918\end{array}$ \\
\hline $\begin{array}{l}\text { 56: Apparel and Accessory Stores } \\
\text { \% Corporate }\end{array}$ & $\begin{array}{l}69,500 \\
.613\end{array}$ & $\begin{array}{c}101,400 \\
.903\end{array}$ & $\begin{array}{c}1,141 \\
.905\end{array}$ \\
\hline $\begin{array}{l}\text { 57: Furniture and Home Furnishing Stores } \\
\qquad \% \text { Corporate }\end{array}$ & $\begin{array}{c}82,310 \\
.633\end{array}$ & $\begin{array}{c}92,970 \\
.870\end{array}$ & $\begin{array}{l}701 \\
.849\end{array}$ \\
\hline $\begin{array}{c}\text { 58: Eating and Drinking Places } \\
\% \text { Corporate }\end{array}$ & $\begin{array}{c}335,285 \\
.538\end{array}$ & $\begin{array}{c}194,300 \\
.791\end{array}$ & $\begin{array}{c}6,522 \\
.791\end{array}$ \\
\hline $\begin{array}{l}\text { 59: Miscellaneous Retail } \\
\text { \% Corporate }\end{array}$ & $\begin{array}{c}240,015 \\
.546\end{array}$ & $\begin{array}{c}183,400 \\
.808\end{array}$ & $\begin{array}{c}1,764 \\
.786\end{array}$ \\
\hline
\end{tabular}

Source: Author's calculations 
Table 2: State Level Data Summary

\begin{tabular}{|c|c|}
\hline & \\
\hline Ln (GSP 1991) & $11.174(1.039)$ \\
Ln (GSP 1992) & $11.118(1.040)$ \\
GSP Growth 1991 to 1992 & $.058(.026)$ \\
$\%$ 1990 Population Born in state & $.610(.141)$ \\
$\%$ Born in the state still there in 1990 & $.635(.084)$ \\
\% Rural & $.318(.147)$ \\
\% with Some College Education & $.452(.066)$ \\
Relative Tax Term & $.035(.021)$ \\
$\mathrm{t}$ Corporate (including federal) & $.391(.020)$ \\
$\mathrm{t}$ Personal (including federal) & $.356(.024)$ \\
Number of observations & 49 \\
\hline
\end{tabular}

Source: Author's calculations 
Table 3: Basic Results-3 Digit SIC Code Level for Corporate Share

\begin{tabular}{|c|c|c|c|c|c|}
\hline & $\begin{array}{c}(1) \\
\text { Firms } \\
\end{array}$ & $\begin{array}{c}(2) \\
\text { Estab }\end{array}$ & $\begin{array}{c}\text { (3) } \\
\text { Employment }\end{array}$ & $\begin{array}{c}(4) \\
\text { Payroll }\end{array}$ & $\begin{array}{c}(5) \\
\text { Sales } \\
\end{array}$ \\
\hline Tax Term & $-.599(.127)$ & $-.376(.124)$ & $-.299(.115)$ & $-.166(.119)$ & $-.258(.127)$ \\
\hline $\ln ($ GSP 91) & $.041(.104)$ & $-.014(.101)$ & $.011(.094)$ & $.080(.097)$ & $-.007(.103)$ \\
\hline $\ln$ (GSP 92) & $-.009(.111)$ & $.044(.109)$ & $-.003(.100)$ & $-.086(.103)$ & $-.000(.109)$ \\
\hline$\%$ Rural & $-.077(.028)$ & $-.113(.028)$ & $-.093(.026)$ & $-.101(.027)$ & $-.101(.028)$ \\
\hline$\%$ Some College & $-.163(.059)$ & $-.187(.058)$ & $-.185(.053)$ & $-.204(.055)$ & $-.260(.059)$ \\
\hline$\%$ Stay in State & $-.155(.052)$ & $-.042(.051)$ & $-.055(.046)$ & $-.064(.048)$ & $-.018(.051)$ \\
\hline$\%$ Born in Stay & $-.115(.024)$ & $-.079(.024)$ & $-.037(.022)$ & $-.037(.023)$ & $-.065(.024)$ \\
\hline ln (land area) & $-.052(.003)$ & $-.040(.002)$ & $-.022(.002)$ & $-.015(.002)$ & $-.024(.002)$ \\
\hline $\ln$ (population) & $-.002(.020)$ & $-.021(.021)$ & $-.018(.019)$ & $-.007(.020)$ & $-.010(.022)$ \\
\hline $\ln$ (employment) & $-.084(.019)$ & $-.023(.019)$ & $-.028(.019)$ & $-.009(.019)$ & $-.003(.020)$ \\
\hline ln (\# firms) & $-.023(.011)$ & $-.101(.010)$ & $-.035(.010)$ & $-.002(.010)$ & $-.012(.011)$ \\
\hline ln (\# establish.) & $-.059(.016)$ & $.036(.016)$ & $-.049(.015)$ & $-.060(.015)$ & $-.086(.016)$ \\
\hline ln (sales) & $-.030(.016)$ & $-.036(.015)$ & $-.045(.014)$ & $-.069(.015)$ & $-.057(.016)$ \\
\hline $\ln$ (payroll) & $.184(.021)$ & $.131(.020)$ & $.175(.020)$ & $.162(.020)$ & $.183(.022)$ \\
\hline Industry Dums. & Yes (38) & Yes (38) & Yes (38) & Yes (38) & Yes (38) \\
\hline obs & 1783 & 1783 & 1647 & 1647 & 1647 \\
\hline $\mathrm{R} 2$ & .72 & .71 & .66 & .57 & .63 \\
\hline Mean of Dep Var & .626 & .698 & .860 & .826 & .830 \\
\hline
\end{tabular}

Notes: The dependent variable is the corporate share of the variable listed at the top of the column. The independent variables are defined in the text. The standard errors are listed in parentheses. 
Table 4: Results at Different Levels of Aggregation

\begin{tabular}{|c|c|c|c|c|c|c|}
\hline & $\begin{array}{c}(1) \\
\text { SIC 2-digit } \\
\text { Firms }\end{array}$ & $\begin{array}{c}(2) \\
\text { SIC 2-digit } \\
\text { Empl. }\end{array}$ & $\begin{array}{c}(3) \\
\text { SIC 2-digit } \\
\text { Sales }\end{array}$ & $\begin{array}{c}(4) \\
\text { SIC 4-digit } \\
\text { Firms }\end{array}$ & $\begin{array}{c}(5) \\
\text { SIC 4-digit } \\
\text { Empl. }\end{array}$ & $\begin{array}{c}\text { SIC 4-digit } \\
\text { Sales }\end{array}$ \\
\hline \multirow{2}{*}{ Tax Term } & -.489 & -.211 & -.196 & -.640 & -.408 & -.359 \\
& $(.202)$ & $(.106)$ & $(.170)$ & $(.154)$ & $(.121)$ & $(.147)$ \\
Other Controls & 13 Vars & 13 Vars & 13 Vars & 13 Vars & 13 Vars & 13 Vars \\
Industry Dums. & Yes (8) & Yes (8) & Yes (8) & Yes (30) & Yes (30) & Yes (30) \\
obs & 391 & 391 & 391 & 1343 & 1216 & 1216 \\
R2 & .73 & .79 & .57 & .62 & .70 & .63 \\
\hline
\end{tabular}

Notes: The dependent variable is the corporate share of the variable listed at the top of the column. The first three columns use a sample of 2-digit industries. The last three columns use a sample of 4-digit industries. Each of the regressions includes the same 13 covariates that were listed in the regressions of table 3 . The standard errors are listed in parentheses. 
Table 5: Robustness

\begin{tabular}{|c|c|c|c|c|c|c|}
\hline & $\begin{array}{c}\text { (1) } \\
\text { Pop weight } \\
\text { Firms } \\
\end{array}$ & $\begin{array}{c}\text { (2) } \\
\text { Pop weight } \\
\text { Empl. }\end{array}$ & $\begin{array}{c}(3) \\
\text { Pop weight } \\
\text { Sales } \\
\end{array}$ & $\begin{array}{c}(4) \\
\text { Median } \\
\text { Firms } \\
\end{array}$ & $\begin{array}{c}\text { (5) } \\
\text { Median } \\
\text { Empl. }\end{array}$ & $\begin{array}{c}(6) \\
\text { Median } \\
\text { Sales } \\
\end{array}$ \\
\hline Tax Term & $\begin{array}{l}-.448 \\
(.150)\end{array}$ & $\begin{array}{l}-.318 \\
(.120)\end{array}$ & $\begin{array}{l}-.388 \\
(.132)\end{array}$ & $\begin{array}{l}-.937 \\
(.165)\end{array}$ & $\begin{array}{l}-.440 \\
(.104)\end{array}$ & $\begin{array}{c}-.402 \\
(.083)\end{array}$ \\
\hline $\begin{array}{l}\text { Other Controls } \\
\text { Industry Dums. }\end{array}$ & $\begin{array}{l}13 \text { Vars } \\
\text { Yes (38) }\end{array}$ & $\begin{array}{l}13 \text { Vars } \\
\text { Yes }(38)\end{array}$ & $\begin{array}{l}13 \text { Vars } \\
\text { Yes }(38)\end{array}$ & $\begin{array}{l}13 \text { Vars } \\
\text { Yes (38) }\end{array}$ & $\begin{array}{l}13 \text { Vars } \\
\text { Yes (38) }\end{array}$ & $\begin{array}{l}13 \text { Vars } \\
\text { Yes (38) }\end{array}$ \\
\hline $\begin{array}{l}\text { obs } \\
\text { R2 }\end{array}$ & $\begin{array}{c}1783 \\
.68\end{array}$ & $\begin{array}{c}1647 \\
.68\end{array}$ & $\begin{array}{c}1647 \\
.64\end{array}$ & $\begin{array}{c}1783 \\
--\end{array}$ & $\begin{array}{c}1647 \\
--\end{array}$ & $\begin{array}{c}1647 \\
--\end{array}$ \\
\hline
\end{tabular}

Notes: The dependent variable is the corporate share of the variable listed at the top of the column. The first three columns weight observations by state population.. The last three columns use median regressions. Each of the regressions includes the same 13 covariates that were listed in the regressions of table 3 . The standard errors are listed in parentheses.

Table 6: Tax Sensitivity by Industry's Average Firm Size

\begin{tabular}{|c|c|c|c|c|c|c|}
\hline & $\begin{array}{c}(1) \\
<2 \text { est/firm } \\
\text { Firms }\end{array}$ & $\begin{array}{c}\exists 2 \text { est/firm } \\
\text { Firms }\end{array}$ & $\begin{array}{c}(3) \\
<2 \text { est/firm } \\
\text { Empl. }\end{array}$ & $\begin{array}{c}(4) \\
\exists 2 \text { est/firm } \\
\text { Empl. }\end{array}$ & $\begin{array}{c}(5) \\
<2 \text { est/firm } \\
\text { Sales }\end{array}$ & $\begin{array}{c}\exists 2 \text { est/firm } \\
\text { Sales }\end{array}$ \\
\hline Tax Term & -.684 & -.024 & -.377 & -.093 & -.336 & -.163 \\
& $(.133)$ & $(.427)$ & $(.118)$ & $(.236)$ & $(.132)$ & $(.169)$ \\
Other Controls & 13 Vars & 13 Vars & 13 Vars & 13 Vars & 13 Vars & 13 Vars \\
Industry Dums. & Yes & Yes & Yes & Yes & Yes & Yes \\
obs & 1569 & 214 & 1451 & 196 & 1451 & 196 \\
R2 & .70 & .78 & .66 & .88 & .62 & .94 \\
\hline
\end{tabular}

Notes: The dependent variable is the corporate share of the variable listed at the top of the column. Columns (1), (3) and (5) look at industries where firms have, on average, average fewer than 2 establishments. Columns (2), (4), and (6) show those having greater than or equal to 2. Each of the regressions includes the same 13 covariates that were listed in the regressions of table 3. The standard errors are listed in parentheses. 
Table 7: Explaining Tax Sensitivity Across States and Industries

\begin{tabular}{|c|c|c|c|c|c|c|}
\hline & $\begin{array}{c}(1) \\
\text { Firms }\end{array}$ & $\begin{array}{c}\text { (2) } \\
\text { Empl. }\end{array}$ & $\begin{array}{c}(3) \\
\text { Sales } \\
\end{array}$ & $\begin{array}{c}(4) \\
\text { Firms } \\
\end{array}$ & $\begin{array}{c}5) \\
\text { Empl. }\end{array}$ & $\begin{array}{c}(6) \\
\text { Sales } \\
\end{array}$ \\
\hline Tax Term & $\begin{array}{l}-3.066 \\
(1.442)\end{array}$ & $\begin{array}{l}-1.729 \\
(1.319)\end{array}$ & $\begin{array}{l}-1.214 \\
(1.456)\end{array}$ & $\begin{array}{l}-6.534 \\
(1.012)\end{array}$ & $\begin{array}{l}-3.092 \\
(.947)\end{array}$ & $\begin{array}{l}-2.519 \\
(1.047)\end{array}$ \\
\hline $\begin{array}{l}\frac{\text { Tax Term }}{\text { Interacted with: }} \\
\text { Industry-Level } \\
\text { Expenses/Sales }\end{array}$ & $\begin{array}{c}2.636 \\
(1.534)\end{array}$ & $\begin{array}{c}1.528 \\
(1.404)\end{array}$ & $\begin{array}{c}1.021 \\
(1.549)\end{array}$ & & & \\
\hline Ln (Population) & & & & $\begin{array}{l}.427 \\
(.116)\end{array}$ & $\begin{array}{l}.034 \\
(.107)\end{array}$ & $\begin{array}{l}-.022 \\
(.118)\end{array}$ \\
\hline Ln (land) & & & & $\begin{array}{l}.515 \\
(.094)\end{array}$ & $\begin{array}{l}.261 \\
(.089)\end{array}$ & $\begin{array}{l}.217 \\
(.098)\end{array}$ \\
\hline $\begin{array}{l}\text { Other Controls } \\
\text { Industry Dums. }\end{array}$ & $\begin{array}{c}13 \text { Vars } \\
\text { Yes (38) }\end{array}$ & $\begin{array}{l}13 \text { Vars } \\
\text { Yes }(38)\end{array}$ & $\begin{array}{l}13 \text { Vars } \\
\text { Yes (38) }\end{array}$ & $\begin{array}{l}13 \text { Vars } \\
\text { Yes }(38)\end{array}$ & $\begin{array}{l}13 \text { Vars } \\
\text { Yes }(38)\end{array}$ & $\begin{array}{l}13 \text { Vars } \\
\text { Yes (38) }\end{array}$ \\
\hline $\begin{array}{l}\text { obs } \\
\text { R2 }\end{array}$ & $\begin{array}{c}1783 \\
.72\end{array}$ & $\begin{array}{c}1647 \\
.66\end{array}$ & $\begin{array}{c}1647 \\
.63\end{array}$ & $\begin{array}{c}1783 \\
.72\end{array}$ & $\begin{array}{c}1647 \\
.66\end{array}$ & $\begin{array}{c}1647 \\
.63\end{array}$ \\
\hline
\end{tabular}

Notes: The dependent variable is the corporate share of the variable listed at the top of the column. The first three columns interact the tax term with the expense ratio, as defined in the text. The last three columns interact the tax term with the size of the state in terms of land and population. Each of the regressions includes the same 13 covariates that were listed in the regressions of table 3 . The standard errors are listed in parentheses. 


\section{APPENDIX TABLE: SIC CODES INCLUDED}

2-Digit SIC code regressions

5200 Building Materials and Garden Supplies Stores

5300 General Merchandise Stores

$5400 \quad$ Food Stores

5500 Automotive Dealers

5600 Apparel and Accessory Stores

5700 Furniture and Homefurnishings Stores

3-Digit SIC code regressions

5210 Lumber \& Other Building Mtrls Dealers

5230 Paint, Glass, and Wallpaper Stores

5250 Hardware Stores

5260 Nurseries, Lawn \& Garden Stores

5270 Manufactured (Mobile) Home Dealers

5310 Department Stores

5330 Variety Stores

5390 Misc. General Merchandise Stores

5410 Grocery Stores

5420 Meat and Fish (Seafood) Markets

5430 Fruit and Vegetable Markets

5440 Candy, Nut, and Confectionery Stores

5450 Dairy Products Stores

5460 Retail Bakeries

5490 Miscellaneous Food Stores

5510 New and Used Car Dealers

5520 Used Car Dealers

5530 Auto and Home Supply Stores

5540 Gasoline Service Stations

\section{4- Digit SIC code regressions}

5712

5713

5714

5719

5731

5734

5735

5736

5812

5813

5941

5942

5943

5944

5945

5946

5947

5948

5949

5961

5962

5963

5983

5984

5989

5992

5993

5994

5995

5999
Furniture Stores

Floor Covering Stores

Drapery, Curtain, Upholstery Stores

Miscellaneous Homefurnishings Stores

Radio, TV, and Electronics Stores

Computer and Software Stores

Record and Prerecorded Tape Stores

Musical Instrument Stores

Eating Places

Drinking Places

Sporting Goods and Bicycle Shops

Book Stores

Stationery Stores

Jewelry Stores

Hobby, toy, and game shops

Camera and photographic supply stores

Gift, novelty, and souvenir shops

Luggage and leather goods stores

Sewing, needlework, piece good stores

Catalog and Mail-Order Houses

Automatic Merchandising Machine Ops.

Direct Selling Establishments

Fuel Oil Dealers

Liquefied Petroleum Gas Dealers

Fuel Dealers, N. E. C.

Florists

Tobacco Stores and Stands

News Dealers and Newsstands

Optical Goods Stores

Miscellaneous Retail Stores, N.E.C.
5550 Boat Dealers

5560 Recreational Vehicle Dealers

5570 Motorcycle Dealers

5590 Automotive Dealers, N. E. C.

5610 Men's Clothing \& Accessory Stores

5620 Women's Clothing Stores

5630 Women's Accessory \& Specialty Stores

5640 Children's and Infants' Wear Stores

5650 Family Clothing Stores

5660 Shoe Stores

5690 Misc. Apparel and Accessory Stores

5720

5730

5910

5920

5930

5940

5960

5980
Household Appliance Stores

Radio, TV, Computer, \& Music Stores

Drug and Proprietary Stores

Liquor Stores

Used Merchandise Stores

Miscellaneous Shopping Goods Stores

Nonstore Retailers

Fuel Dealers 


\section{BIBLIOGRAPHY}

Ayers, B., C. Cloyd and J. Robinson (1996), "Organizational Form and Taxes: An Empirical Analysis of Small Businesses" Journal of the American Tax Association Supplement 18: 49-67.

Ballard, C., J. Shoven and J. Whalley (1985), "The Total Welfare Cost of the United States Tax System: A General Equilibrium Approach" National Tax Journal 38(2) pp. 125-140.

Carroll, R. and D. Joulfaian (1997), "Taxes and Corporate Choice of Organizational Form," U.S. Department of the Treasury, Office of Tax Analysis Working Paper 73, October.

Feldstein, M., J. Dicks-Mireaux and J. Poterba (1983), "The Effective Tax Rate and the Pretax Rate of Return," Journal of Public Economics v. 21, pp. 129-158.

Fullerton, D and D. Rogers (1993), Who Bears the Lifetime Tax Burden. Brookings, Wash. D.C.

Gentry, W. (1994), "Taxes, Financial Decisions and Organizational Form: Evidence from Publicly Traded Partnerships” Journal of Public Economics v33 \#2 pp. 223-244.

Goolsbee, Austan (1998), "Taxes, Organizational Form and the Deadweight Loss of the Corporate Income Tax," Journal of Public E conomics, vol.69, July: 143-152.

Goolsbee, A. and E. Maydew (2000), 'Coveting Thy Neighbor's Manufacturing: The Dilemma of State Income Apportionment," Journal of Public Economics, January, vol. 75(1): 125-143.

Gordon, R. and J. Mackie-Mason (1990), "Effects of the Tax Reform Act of 1986 on Corporate Financial Policy and Organizational Form" pp. 91-131 in J. Slemrod, ed. Do Taxes Matter, MIT Press, Cambridge, Mass.

Gordon, R. and J. Mackie-Mason (1994), "Tax Distortions to the Choice of Organizational Form" Journal of Public Economics v. 55, pp. 279-306.

Gordon, R. and J. Mackie-Mason (1997), "Taxes and the Choice of Organizational Form" Journal of Finance.

Gordon, R. and R. Wilson (1986), "An Examination of Multijurisdictional Corporate Income Taxation Under Formula Apportionment," Econometrica 54(6), pp. 1357-73.

Gravelle, J. and L. Kotlikoff (1988), "Does the Harberger Model Greatly Understate the Excess Burden of the Corporate Income Tax?" NBER Working Paper \# 2742.

Gravelle, J. and L. Kotlikoff (1989), "The Incidence and Efficiency Costs of Corporate Taxation When Corporate and Noncorporate Firms Produce the Same Good" Journal of Political Economy 97(4) pp. 749-780. 
Gravelle, J. and L. Kotlikoff (1993), "Corporate Tax Incidence and Inefficiency When Corporate and Noncorporate Goods are Close Substitutes," Economic Inquiry

Guenther, D. (1992), "Taxes and Organizational Form: A Comparison of Corporations and Master Limited Partnerships," The Accounting Review 67 (January): 17-45.

Harberger, A. (1966), "Efficiency Effects of Taxes on Income from Capital" pp. 107-117 in M. Krzyzaniak Effects of the Corporation Income Tax. Wayne State University Press; Detroit.

Levin, Jonathan and Steven Tadelis (2002), "A Theory of Partnerships," Mimeo, Stanford University, April.

Omer, T., G. Plesko, and M. Shelley (2000), "The Influence of Tax Costs on Organizational Choice in the Natural Resource Industry," Journal of the American Tax Association, 22(1), Spring: 38-55.

Plesko, G. (1995), "The Role of Taxes in Organizational Choice: S Conversions After the Tax Reform Act of 1986," mimeo, M.I.T. Sloan School

Scholes, M. and M. Wolfson (1990), "The Effects of Changes in Tax Laws on Corporate Reorganization Activity" Journal of Business 63(1) pp. pp. S141-S164.

Scholes, M. and M. Wolfson (1991), "The Role of Tax Rules in the Recent Restructuring of U.S. Corporations" pp. 1-25 in D. Bradford ed. Tax Policy and the Economy v 5.

Scholes, M., M. Wolfson, M. Erickson, E. Maydew, and T. Shevlin (2002), Taxes and Business Strategy: A Planning Approach. Englewood Cliffs: Prentice-Hall.

Shoven, J. (1976), "The Incidence and Efficiency Effects of Taxes on Income from Capital" Journal of Political Economy December, pp. 1241-1283. 


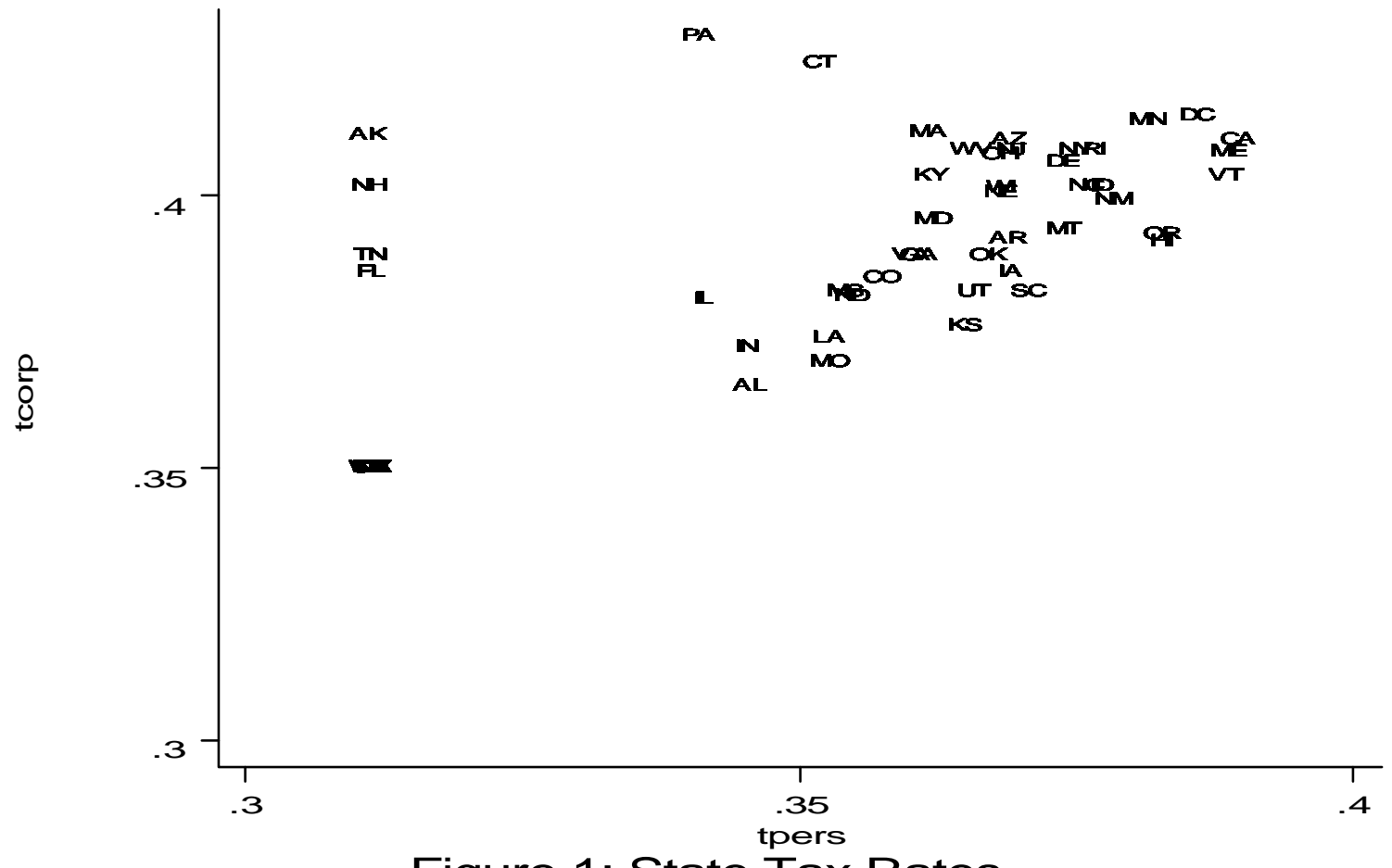

Figure 1: State Tax Rates 